\title{
On the Politics of Book Giving books2prisoners Ottawa
}

\section{$\mathrm{B}$}

ooks2prisoners Ottawa is just one of hundreds of groups in North America who send books and other reading material into prisons and jails. Prison and jail conditions are sometimes akin to deprivation chambers, as numerous prisoner writings in the Journal of Prisoners on Prisons attest. We think access to reading and educational material is extremely important in making it through the experience of imprisonment. We often receive letters from those to whom we have sent books, and they express how much receiving and reading books helps them survive inside. We send books as a sign of solidarity.

Yet books2prisoners Ottawa is not a charity. We are not motivated by some notion of salvation for us or for the prisoners. Instead, we are interested in tearing down the walls that stand between prisoners and those outside who have not yet been caught up in the criminalizing machine that is "criminal justice" in North America. In this regard, an equally significant part of what we do is organizing events that try to educate the general public about the politics of imprisonment. We are alarmed by the latest "get tough" move in criminal justice policy by the Harper Conservatives in Canada towards mandatory minimums, more prisons, detention and rendition, and support of and assistance in torture. With limited resources we attempt to let people know that these kinds of prison-intensification programs can be struggled against, and are being struggled against by folks inside and outside. We do not think more "humane" prisons and jails are desirable or even possible because prisons and jails are about practicing and perpetuating violence.

We are a small book sending and prisoner solidarity crew, but sometimes more good work gets done in smaller affinity groups than bigger, unwieldy organizations. Our books are received by donation and sometimes we buy prisoners a book if it is something specific like an astrophysics text. Funds are raised for mail-outs through organizing benefit concerts and through pay-what-you-can books sales. Via regular mail, we send books to individual prisoners in Canada and the United States. In addition to individual letters, we sometimes send larger requests - upwards of a thousand books - through Corrections Service of Canada (CSC) to federal prisons. Even though CSC has an explicit education mandate, many CSC prisons do not have libraries or educational programming. This is appalling. The issue is even more disconcerting in provincial jails and detention centres that do not have educational programming. Reconciling our abolitionist politics and our liaising with 
CSC is not always easy, and we are trying to come up with ways to be even more autonomous.

There are many other groups that go by different names BooksthruBars, BooksforPrisoners and so on - and not all groups share the same politics. A group in Boston focuses only on sending books to women inside prisons. There is a group in Oregon that runs out of a closet in a mechanic's garage. There are groups in Indiana and Texas that have gigantic computer systems for keeping track of who sent what, where and when, which move thousands of books every week!

The book sending movement actually finds one of its roots in the prisoner solidarity efforts of the anarchist black cross (ABC) network. Books2prisoners Ottawa can trace its beginnings to $\mathrm{ABC}$ prisoner solidarity work being done in Montreal in the late 1990s.

More books2prisoner and prisoner solidarity groups pop up in Canada every month. Groups have recently started up in Regina, Winnipeg and Toronto. At the 2008 anarchist book fair in Montreal, different books2prisoner groups from Canada met for the first time to discuss how they operate and how they can work together on various projects. While all the groups operate autonomously, a national list serve was created to communicate about common concerns. At a broader level, whether it is folks organizing inside or outside, we are all struggling against bloated and corrupt bureaucracies, and we do not want to emulate them in any way.

\section{CONTACT INFORMATION}

books2prisoners

Carleton University

326 Unicentre

1125 Colonel By Drive

Ottawa, Ontario

K1S 5B6 